\title{
DEVELOPING MULTIMEDIA-BASED INTERACTIVE LEARNING MEDIA ON FOOTBALL LEARNING COURSES
}

\author{
Ahmad Al Munawar*, Dicky Hendrawan \\ Correspondence: STOK Bina Guna, Medan, Indonesia \\ E-mail: a.almunawar16@gmail.com
}

\begin{abstract}
The purpose of this study is to develop multimedia-based interactive learning media on football subject. This research method is R\&D, development research where product development consists of four steps namely (1) Define, (2) Design, (3) Development and (4) Dissemination. The population and sample in this study were all class students of 2017 who took football courses at STOK of Bina Guna Medan. Data collection techniques were conducted by observation, interview and questionnaire. The testing phase was carried out with product validation by two media experts, and two material experts, as well as testing on users (students). The data analysis technique used is descriptive analysis technique. The results of this study are: (1) based on two media experts, the score is 83.33 with the category "very appropriate" to be used as a learning medium. (2) based on two material experts, the score was 71.53 with the appropriate category to be used as learning media. (3) based on the assessment by the students gained a total score of 75.90 with the category "very appropriate" as a learning media. Based on the above results, multimedia-based interactive learning media on football learning subject can be used as learning media.
\end{abstract}

\section{Keywords: Learning media, Football Introduction}

\section{Journal Physical Education. Health and Recreation}

KKNI eurriculum is implemented by Sports and Health College of Bina Guna (STOK) to fulfill national curriculum standard and as a university in North Sumatra which is responsible for producing productive human resources. Technological developments and changes in globalization towards the digital era are challenges that must be balanced with the lecture process towards developments which occur to strengthen the commitment of university to emphasize character education and increase productivity, especially in lectures.

The lecture method faced at this time faces many obstacles when dealing with the limitations of the place and time of implementation, as related to the increasing number of students and learning and students' activities in the global era, it is necessary for students to be given learning experiences with varied learning sources and media. The learning paradigm thus began to shift from face to face learning (face to face course) directly to web-based learning (web-based courses) such as video conference and e-learning, Asyhar R (2012). 
Technology in sports is very helpful for coaches and athletes in implementing training programs, Endang, Nindiea (2019). Training becomes more precise and accurate because of technological assistance. Many technologies found in sports have an important role, one of them is technology in badminton. The role of technology in the development of sports achievements is so minimum that training is only applied manually Endang, Nindiea (2019). In research, researchers utilize technology by developing multimedia-based learning media in football subject.

Media is a tool or medium used to convey messages from communicators to the public, Cangara (2006). There are several psychologists who view that in communication between humans, the most dominating media in communication is the human senses such as the eyes and ears. Media is anything which can be used to channel messages from the sender and receiver so that they can stimulate the thoughts, feelings, attention and interests and athletes' attention in such a way that the training process occurs, Riza Fahmi et al (2018).

The Football course is one of the courses in Physical Health and Recreation Education (PJKR) which is applied to students. Football course gives an experience for students to be able to apply-Football skills and understand teaching methods to football techniques. The problem which arises in the lecture process is that students have a low cognitive knowledge which is $30 \%$ of the average ability based on the results of midterms (UTS) in October 2018. It takes an effort to handle in giving knowledge to students practically and can be permanently attached to students. Changes in globalization currently leading to the global era of digitalization make the process of lectures should develop learning systems, one of which is by utilizing multimedia application technology as an innovative development of soccer lectures that has an important role for students in improving lecture competence.

\section{Method Journal Physical Education, Health and Recreation}

The research method is $R \& D$, development research in which product development consists of four steps namely (1) Define, (2) Design, (3) Development and (4) Dissemination. Sugiyono (2008) research and development method is research method used to produce certain products, and test the effectiveness of these products so that they function in the wider community.

The population and sample in this study are all class students of 2017 who took football course at STOK of Bina Guna Medan. Data collection techniques were conducted by observation, interview and questionnaire. The testing phase is carried out with product validation by two media experts, and two material experts, as well as testing on users (students). The data analysis technique used is descriptive analysis technique. The development phase in detail is as follows:

a. Define : Define stage is the stage of determining the problem to be raised in this study, at this stage the needs analysis is carried out as a preliminary research step by conducting observation and interview. Interview is conducted 
with football learning lecturers in the campus environment of STOK Bina Guna in obtaining the data needed for the design stage.

As for the data taken in this needs analysis namely student learning outcomes in midterm football learning subject (UTS) which are less satisfactory. From the results of learning, students have a low cognitive knowledge that is $30 \%$ of average ability, whereas the performance motorically shown is inversely proportional. This is the basis for researchers to make efforts to provide cognitive knowledge to students in a practical and permanent way.

b. Design: After going through the needs analysis stage, the researchers discussed with several education experts about the right solution to the problem at hand, from the results of the discussion, it was gotten that the conclusion of making a multimedia-based application which is practical and easy to access anytime and anywhere. Furthermore, researchers determine the design of the application referred to by the stages of determination;

1. Model Making. The model in this learning media application uses the thumb focused interaction model or the interaction which is focused on using the thumb, Goldengekko (2014). This model aims the application can be run using one hand without difficulty reaching the menu as shown in the Figure below.

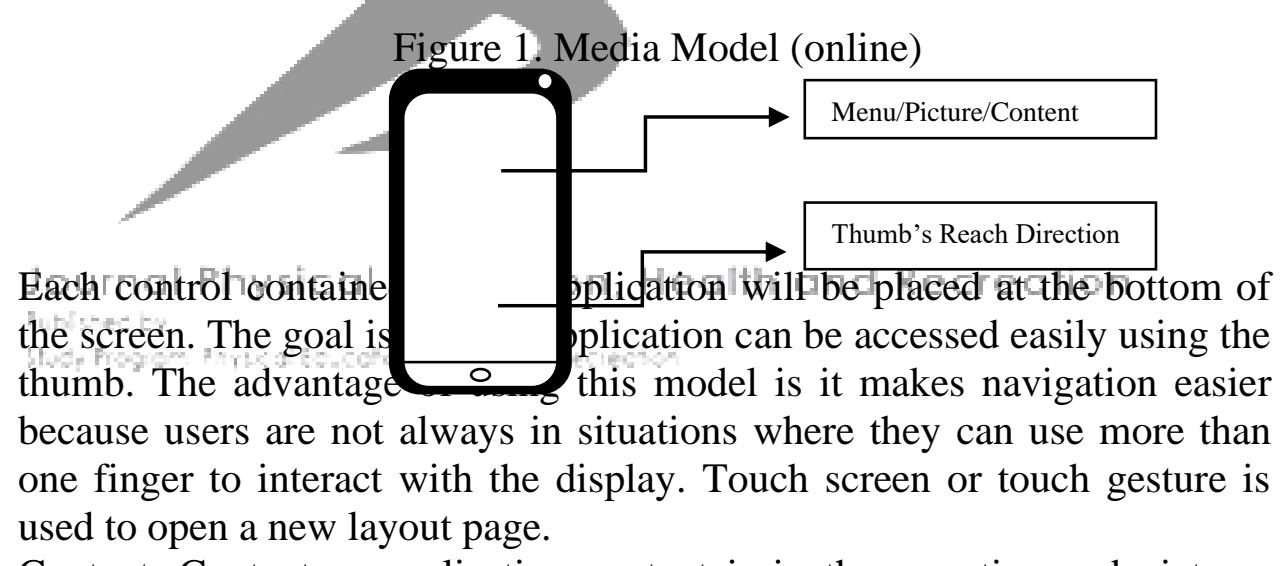

2. Content. Content or application content is in the narrative and pictures forms of the basic techniques of football. This application has the purpose of displaying images, texts and videos. Pictures and texts are used to explain the subject matter. The images used are component symbol images, series drawings, illustrated drawings and symbol drawings. While the video is a database stored in the application that will be accessed by users anytime.

c. Development: Development stage has the aim to produce learning tools that have been revised based on input from experts. The design stages include: 
Figure 2. Developing Design, Sugiyono (2008)

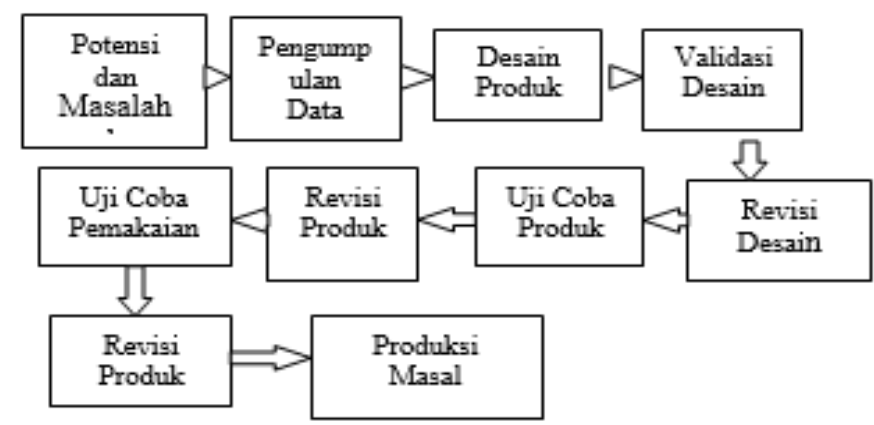

d. Validation: Validation is a step or effort in seeing the appropriateness of application which has been designed in the form of the appearance or the contents of application itself. Validation test aims to determine the appropriateness of the product before the next stage is carried out. The validation test in this study was conducted by 4 experts namely 2 application media experts and 2 football learning lecturers. Validation by experts will produce data and suggestion that are used to improve software in the first stage while two football instructors will produce data and suggestion in the realm of content / material.

e. Small Group Trials: Small group trials are conducted in other classes that have the same characteristics as the class which is the main subject in this study. As for the classes that was taken in this small group trial are the V-A semester students who have received the same material which is football learning. The implementation of the activities in this trial is $_{\text {s }}$ in the form of distributing questionnaires to the learning media (application). From this distribution researchers can retrieve data in the form of the appropriateness and effectiveness of the product which will be tested in the actual subject.

f. Revision by experts: Experts in this activity are the main key in the perfection of products designed, from the opinion and judgment of competent experts will produce competent products as well. Expert revision is needed after small group trial activities are carried out, to be able to see firsthand the advantage and usefulness of the product being developed.

g. Large Group Trial: In the next stage is the appropriateness test on the actual subject, namely students in semester III-D by total 30 people. Of the several stages which have been passed, the learning products or media will be distributed to students to be tested and assessed for their usefulness, efficiency and practicality in their use. 
h. Revision II by experts: The second revision is the final revision before the product or media is widely distributed.

i. Production: Production stage is the final stage of making media after a series of stages and revisions which have been passed. This stage, the product / media / application has been declared that it is ready to use and perfect.

j. Dissemination: The dissemination stage is the stage of using devices which have been developed on a broader scale such as in other classes on different campuses by different lecturers, which aims to test the effectiveness of the devices use in teaching and learning activities.

\section{Discussion}

Learning media designed aimed to give easiness for students to access it via Smartphones. Before using learning media files / applications are sent to the user via Bluetooth or via instant messages such as WhatsApp. After the file is sent, students can install it by themselves on their Smartphone. This is in accordance with the rules of learning media stated by Arsyad (2010), that this learning media is easy to reproduce. The main material in this media is the basic technique of football which consists of dribble techniques, passing techniques, shooting techniques, heading techniques, and trapping techniques.

The appropriateness of this learning media has been assessed based on two media experts and two material experts. The assessment of the appropriateness of learning media applications by media experts was assessed based on 3 aspects, namely aspects of learning media, governance and media. The average of total score of evaluation by media experts was 112.00 (the "very appropriate" category). Then the score is converted in the form of a standard score with a range of 0 to 100 . The score value after being converted was 83.33 so it can be said that the appropriateness of learning media based on the assessment by media experts in the category was very appropriate to be used as a learning media. Assessment of the appropriateness of learning media by material experts was assessed based on 3 aspects, for instance the aspects of learning media, governance and relevance to the syllabus of the course. The average of total score of assessment by two material experts was 75.50 (the "appropriate" category). Then, the score was converted in the form of a standard score with a range of 0 to 100. The score after being converted was 71.53 so that it can be said that the appropriateness of learning media based on the assessment by media experts in the appropriate category was used as learning media. Assessment of the appropriateness of learning media by students was assessed based on 3 aspects, they are aspects of learning media rules, aspects of media and aspects of relevance to the syllabus of the course. The mean of total score of assessment by students was 75.90 (the category of "very appropriate"). Then the score was converted in the form of a standard score with a range of 0 to 100 . The score after being converted was 76.67 and states that learning media in the "very appropriate" category as learning media. 


\section{Conclusion}

The results of research and discussion on the development of multimediabased interactive learning media on football learning subject namely; media development based on syllabus in football course at Sports and Health College of Bina Guna (STOK) with competency standards students is able to perform basic technical skills of football properly and correctly.

The subject presented is the basic technique of a football game consisting of passing techniques, heading techniques, shooting techniques, trapping techniques in addition to this media also provides evaluation menus that can be used as exercises in the form of multiple choice questions. The operation of the learning media application is sent via Bluetooth or social media networks such as Whatsapp. Then students can install it on their Smartphone devices.

The appropriateness of this learning media is assessed based on two media experts and two material experts with the following results; (1) based on the media expert got a score of 83.33 with the category "very appropriate" to be used as a learning media. (2) based on two material experts, the score was 71.53 with the appropriate category to be used as learning media. (3) based on the assessment by the students got a total score of 75.90 with the category "very appropriate".

\section{References}

Arsyad A, 2010. Media Pembelajaran. Jakarta: PT Raja Grafindo Persada

Asyhar R, 2012. Kreatif Mengembangkan Media Pembelajaran. Jakarta: Referensi Jakarta.

Cangara. Hafied, 2006. Pengantar Ilmu Komunikasi. Jakarta: PT. Raja Grafindo Persada

Endang S, Nindiea Novselia, 2019. Pengembangan Alat Bantu Latihan Footwork Pada Bulutangkis Berbasis Andorid. Journal Physical Education, Health and Recreation. Volume: 3, Edisi: 2: 122-130.

Goldengekko, 2014. 10 Design Trends 2014 UX/UI trends for mobile solution. http://www.slideshare.net/goldengekko/mobile-apps-design-trends-2014

Riza Fahmi dkk, 2018. Pengaruh Media Audio Visual Dan Demonstrasi Langsung Terhadap Hasil Tendangan Lurus Pada Ukm Tapak Suci Universitas Lampung. Journal Physical Education, Health and Recreation. Volume: 3, Edisi: 1: 43-52.

Sugiyono, 2008. Metode Penelitian Kuantitatif, Kualitatif dan $R \& D$. Bandung: Alfabeta.

PJKR_

http://jurnal.unimed.ac.id/2012/index.php/jpehr 